OPEN ACCESS

Edited by:

Akio Adachi,

Tokushima University, Japan

Reviewed by:

Michael Bukrinsky,

George Washington University,

United States

Jack Thomas Stapleton,

University of lowa, United States

Laurel Lagenaur,

Osel Inc., United States

${ }^{*}$ Correspondence:

Christophe Vanpouille

vanpouic@mail.nih.gov

Specialty section:

This article was submitted to

Virology,

a section of the journal

Frontiers in Microbiology

Received: 23 March 2017

Accepted: 03 May 2017

Published: 19 May 2017

Citation:

Ñahui Palomino RA, Zicari $S$, Vanpouille $C$, Vitali $B$ and Margolis $L$ (2017) Vaginal Lactobacillus Inhibits HIV-1 Replication in Human Tissues

Ex Vivo. Front. Microbiol. 8:906

doi: 10.3389/fmicb.2017.00906

\section{Vaginal Lactobacillus Inhibits HIV-1 Replication in Human Tissues Ex Vivo}

\author{
Rogers A. Ñahui Palomino ${ }^{1,2}$, Sonia Zicari ${ }^{1}$, Christophe Vanpouille ${ }^{1 *}$, Beatrice Vitali ${ }^{2}$ and \\ Leonid Margolis ${ }^{1}$
}

${ }^{1}$ Section of Intercellular Interaction, Eunice Kennedy Shriver National Institute of Child Health and Human Development, National Institutes of Health, Bethesda, MD, United States, ${ }^{2}$ Department of Pharmacy and Biotechnology, University of Bologna, Bologna, Italy

Lactobacillus species, which dominate vaginal microbiota of healthy reproductive-age women, lower the risks of sexually transmitted infections, including the risk of human immunodeficiency virus (HIV) acquisition. The exact mechanisms of this protection remain to be understood. Here, we investigated these mechanisms in the context of human cervico-vaginal and lymphoid tissues ex vivo. We found that all six Lactobacillus strains tested in these systems significantly suppressed HIV type-1 (HIV-1) infection. We identified at least three factors that mediated this suppression: (i) Acidification of the medium. The $\mathrm{pH}$ of the undiluted medium conditioned by lactobacilli was between 3.8 and 4.6. Acidification of the culture medium with hydrochloric acid $(\mathrm{HCl})$ to this $\mathrm{pH}$ in control experiments was sufficient to abrogate HIV-1 replication. However, the $\mathrm{pH}$ of the Lactobacillus-conditioned medium (CM) diluted fivefold, which reached $\sim 6.9$, was also suppressive for HIV-1 infection, while in control experiments HIV-1 infection was not abrogated when the $\mathrm{pH}$ of the medium was brought to 6.9 through the use of $\mathrm{HCl}$. This suggested the existence of other factors responsible for HIV-1 inhibition by lactobacilli. (ii) Lactic acid. There was a correlation between the concentration of lactic acid in the Lactobacillus-CM and its ability to suppress HIV-1 infection in human tissues ex vivo. Addition of lactic acid isomers $D$ and $L$ to tissue culture medium at the concentration that corresponded to their amount released by lactobacilli resulted in HIV-1 inhibition. Isomer $L$ was produced in higher quantities than isomer $D$ and was mostly responsible for HIV-1 inhibition. These results indicate that lactic acid, in particular its L-isomer, inhibits HIV-1 independently of lowering of the $\mathrm{pH}$. (iii) Virucidal effect. Incubation of HIV1 in Lactobacillus-CM significantly suppressed viral infectivity for human tissues ex vivo. Finally, lactobacilli adsorb HIV-1, serving as a sink decreasing the number of free virions. In summary, we found that lactobacilli inhibit HIV-1 replication in human tissue ex vivo by multiple mechanisms. Further studies are needed to evaluate the potential of altering the spectra of vaginal microbiota as an effective strategy to enhance vaginal health. Human tissues ex vivo may serve as a test system for these strategies.

Keywords: Lactobacillus, HIV-1, human tissue, lactic acid, pH 


\section{INTRODUCTION}

The vaginal microbiota of healthy reproductive-age women is generally dominated by Lactobacillus species (Ravel et al., 2011). Lactobacilli are considered to be health-promoting microorganisms since they are involved in maintaining vaginal homeostasis by preventing overgrowth of pathogenic and opportunistic organisms (Ronnqvist et al., 2006; O'Hanlon et al., 2013). Indeed, lactobacilli play a key role in the prevention of numerous urogenital diseases such as bacterial vaginosis and yeast infections as well as sexually transmitted infections, both bacterial (Chlamydia trachomatis, Neisseria gonorrhoeae, Trichomonas vaginalis) and viral. In particular, lactobacilli have been reported to protect against vaginal transmission of human immunodeficiency virus (HIV) (Sewankambo et al., 1997; Atashili et al., 2008; Gosmann et al., 2017).

Although many hypotheses have been formulated regarding the protective effects of lactobacilli, the exact mechanisms of HIV inhibition by vaginal lactobacilli remain to be fully elucidated. These mechanisms seem to involve production of antiviral compounds such as lactic acid, hydrogen peroxide, bacteriocins, and lectins (Aldunate et al., 2013; Petrova et al., 2013). Also, the inhibition of HIV transmission has been reported to be mediated by lactobacilli that affect vaginal epithelia, modulate bacterial vaginosis, or change local or systemic immune responses (Kaewsrichan et al., 2006; Reid et al., 2011).

Here, we investigated the role of vaginal lactobacilli on HIV type-1 (HIV-1) infection of human lymphoid tissues and of human cervico-vaginal tissues ex vivo. The latter in vivo are the first gateway for HIV-1 infection during vaginal virus transmission (Redondo-Lopez et al., 1990). These ex vivo systems have many advantages over the conventional single-cell cultures, as they retain the majority of cell types in the context of native tissue cytoarchitecture. Also, human tissues ex vivo express key cell surface molecules relevant to HIV infection, and this system does not require exogenous activation or stimulation to support productive HIV infection (Grivel and Margolis, 2009).

Here, we found that HIV-1 replication in human tissues ex vivo was significantly suppressed by lactobacilli, and we identified multiple mechanisms of this phenomenon.

\section{MATERIALS AND METHODS}

\section{Lactobacillus Culture Conditions}

Fifteen Lactobacillus strains (L. crispatus BC1, BC3-BC8; L. gasseri $\mathrm{BC} 9-\mathrm{BC} 14$; and L. vaginalis $\mathrm{BC} 16, \mathrm{BC} 17)$, isolated from vaginal swabs of healthy premenopausal women (Parolin et al., 2015), were cultured overnight at $37^{\circ} \mathrm{C}$ in anaerobic jars containing Gaspak EZ (Becton Dickinson) in modified medium. This modified medium contained 75\% Roswell Park Memorial Institute (RPMI) 1640 medium (Gibco BRL, Carlsbad, CA, United States), supplemented with $15 \%$ fetal bovine serum (FBS), sodium pyruvate at $1 \mathrm{mM}$, non-essential amino acids at $1 \mathrm{mM}$, and $25 \%$ de Man, Rogosa, and Sharpe (MRS) broth (Difco, Detroit, MI, United States) supplemented with $0.05 \%$ L-cysteine. The turbidity levels of overnight cultures were adjusted to an optical density conversion factor $\left(\mathrm{OD}_{600 \mathrm{~nm}}\right)$ of 0.5 , corresponding to a cell concentration of $10^{8}$ colony forming units $(\mathrm{CFU}) / \mathrm{mL}$. Culture media were centrifuged at $4,000 \times g$ for $10 \mathrm{~min}$ at $4^{\circ} \mathrm{C}$ and then filtered through a $0.22 \mu \mathrm{m}$ membrane filter. The resultant Lactobacillus-conditioned medium (CM) was then used to treat tissue explants infected by HIV-1. Lactobacillus-cell pellets (CP) were washed in sterile saline solution $(0.9 \% \mathrm{NaCl}$ supplemented with $0.05 \%$ L-cysteine) and resuspended in antibiotic-free modified medium.

\section{Ex Vivo Tissue Cultures and HIV-1 Infection}

Human cervico-vaginal tissue explants obtained from routine hysterectomy (National Disease Research Interchange, Philadelphia, PA, United States) and tonsillar tissue (Children's National Medical Center, Washington, DC, United States) were dissected and cultured as described in Grivel and Margolis (2009) with slight modifications. Briefly, the tonsillar and mucosa layers from ecto- and endo-cervix tissues were cut in blocks of $2 \mathrm{~mm}^{3}$. Eighteen cervico-vaginal tissue blocks were infected with $0.4 \mathrm{~mL}$ of viral stock HIV-1 $\mathrm{BaL}$ (120 ng/mL p24 gag obtained from the Virology Quality Assurance Laboratory at Rush University, Chicago, IL, United States) for $2.5 \mathrm{~h}$ at $37^{\circ} \mathrm{C}$ in agitation. After infection, tissue blocks were washed three times with phosphatebuffered saline (PBS) and transferred at the liquid-air interface onto Gelfoam (nine blocks per well) in a 12-well plate containing RPMI 1640 medium at $1 \mathrm{~mL} /$ well supplemented with 15\% FBS, sodium pyruvate at $1 \mathrm{mM}$, non-essential amino acids at $1 \mathrm{mM}$, gentamicin sulfate at $50 \mu \mathrm{g} / \mathrm{mL}$, amphotericin B at $2.5 \mu \mathrm{g} / \mathrm{mL}$. Twenty-seven tonsillar tissue blocks (nine blocks per well in $3 \mathrm{~mL}$ of RPMI 1640 medium supplemented as above) were placed on collagen sponge gels, and tissue blocks were infected with $7.5 \mu \mathrm{L}$ of viral stock, on top of each block. Cervico-vaginal and tonsillar tissue were incubated at $37^{\circ} \mathrm{C}$ for 12 days, with replacement of culture medium every 3 days. 3TC (lamivudine at $10 \mu \mathrm{M}$ ) was used as a positive control for HIV-1 inhibition.

\section{Lactobacillus Colonization on Tonsillar Explants and Evaluation of Tissue Cell Depletion}

Tonsillar tissues were colonized with 15 vaginal Lactobacillus strains (27 blocks per condition) at a starting inoculum of $10^{4} \mathrm{CFU} / \mathrm{mL}$. At day 3 after inoculation with bacteria, all tissue blocks were collected and digested with collagenase IV $(5 \mathrm{mg} / \mathrm{mL}$; Gibco BRL) for $30 \mathrm{~min}$ with agitation in a Thermomixer at $900 \mathrm{rpm}$ at $37^{\circ} \mathrm{C}$. Following digestion, tissue cells were filtered with $100 \mu \mathrm{m}$ cell strainers (Corning) and washed with $50 \mathrm{~mL}$ of PBS. Cells were then suspended in $1 \mathrm{~mL}$ of PBS and stained with $1 \mu \mathrm{l}$ of live/dead Fixable Viability Dye eFluor 450 (EF 450, Invitrogen) for $15 \mathrm{~min}$. After incubation, cells were washed and diluted in staining buffer [PBS, 1\% normal mouse serum, $1 \%$ normal goat serum, $1 \mathrm{mM}$ ethylenediaminetetraacetic acid (EDTA)] and stained with anti-CD3-allophycocyanin (CD3APC) for $20 \mathrm{~min}$. After surface staining, cells were permeabilized with the Fix\&Perm Cell Fixation and Cell Permeabilization Kit (Invitrogen) then stained for $20 \mathrm{~min}$ with anti-Bcl2-PE, a 
mitochondrial anti-apoptotic antigen. Data were acquired with a Novocyte flow cytometer (ACEA Biosciences, CA, United States) equipped with 405, 488, and $640 \mathrm{~nm}$ laser lines using NovoExpress version 1.2.4 software (ACEA Biosciences) and analyzed using the same software.

\section{HIV-1 Infection of Human Tissues Ex Vivo Treated with Lactobacillus-CM}

Cervico-vaginal and tonsillar tissue blocks were cultured in Lactobacillus-CM from six Lactobacillus strains (L. crispatus BC3, $\mathrm{BC} 5$; L. gasseri $\mathrm{BC} 12, \mathrm{BC} 13$; and L. vaginalis $\mathrm{BC16}, \mathrm{BC} 17)$, obtained as described above. Tissue blocks were pre-incubated with Lactobacillus-CM undiluted and diluted 1:5 with normal medium for $2 \mathrm{~h}$ before HIV-1 infection. After HIV-1 infection, tissue cultures were kept in the same medium (undiluted or diluted 1:5) for the next 3 days of culture, then the medium was replaced with complete RPMI 1640 medium every 3 days, and the culture was kept until day 12 .

\section{Virucidal Effect}

We carried out virucidal experiments by pre-treating HIV-1 with Lactobacillus-CP or Lactobacillus-CM. HIV-1 viral suspensions at $400 \mu \mathrm{L}$ were mixed with $100 \mu \mathrm{L}$ of Lactobacillus-CP (stock $5 \times 10^{8} \mathrm{CFU} / \mathrm{mL}$ ), corresponding to a final concentration of $10^{8} \mathrm{CFU} / \mathrm{mL}$, or $100 \mu \mathrm{l}$ of undiluted Lactobacillus-CM (corresponding to a final 1:5 dilution) or with $100 \mu \mathrm{L}$ of normal medium (experimental control condition). Cultures under these three experimental conditions were then incubated for $60 \mathrm{~min}$ at $37^{\circ} \mathrm{C}$ and centrifuged at $4,000 \times g$ for $10 \mathrm{~min}$ at $4^{\circ} \mathrm{C}$. Supernatants were used to infect cervico-vaginal tissue, as described above.

\section{Lactic Acid Quantification, pH Measurement of Lactobacillus-CM, and Evaluation of Their Effect on HIV-1 Replication}

We quantified titers of lactate isomers D and L from overnightcultured Lactobacillus-CM using a lactate quantification assay kit according to the manufacturer's instructions (BioAssay Systems, EFDLC-100 and EFLLC-100). Isomers D (3 mM), L (23 mM), and $\mathrm{D}+\mathrm{L}(3 \mathrm{mM}+23 \mathrm{mM})$, corresponding to the average titers found in all undiluted Lactobacillus-CM, were tested for HIV-1 inhibition in human cervico-vaginal and lymphoid tissues. Isomers $\mathrm{D}$ and $\mathrm{L}$ at concentrations corresponding to those found in dilution 1:5 were also tested in lymphoid tissues. $\mathrm{pH}$ values in all Lactobacillus-CM, undiluted or diluted 1:5, were measured as well. Furthermore, in order to evaluate the effect of low $\mathrm{pH}$ on HIV-1 replication in tissues ex vivo, as measured in Lactobacillus$\mathrm{CM}$ (undiluted average around $\mathrm{pH} 4$ and diluted 1:5 up to $\mathrm{pH}$ 6.9), we evaluated HIV-1 infectivity in ex vivo tissue at $\mathrm{pH} 4$ and $\mathrm{pH}$ 6.9, buffering the medium with hydrochloric acid $(\mathrm{HCl})$.

\section{Evaluation of HIV-1 Replication}

We evaluated HIV-1 replication on tissue by measuring the levels of $\mathrm{p} 24_{\mathrm{gag}}$ in tissue culture medium using a dynamic immunofluorescent cytometric bead assay as described by Biancotto et al. (2009).

\section{Statistical Analysis}

We performed all statistical analyses using ANOVA test GraphPad Prism version 7 (GraphPad Prism Software Inc., San Diego, CA, United States). Results were deemed significant for $p$-values $<0.05$.

\section{RESULTS}

\section{Lactobacillus Colonization of Tissue Explants}

Fifteen Lactobacillus strains belonging to L. vaginalis, L. gasseri, and L. crispatus were evaluated for their capacity to colonize ex vivo tissue blocks. All lactobacilli colonized tissue explants with similar kinetics, reaching maximum colonization (approximately $10^{8.5} \mathrm{CFU} / \mathrm{mL}$ ) after 3 days of culture, and then plateaued for the entire 12 days of culture duration (Figure 1A). Cell depletion in tissue explants by lactobacilli was evaluated 3 days after bacterial inoculation (Figure 1B). Colonization of explants with 6 out of 15 Lactobacillus strains, L. crispatus (BC3, BC5), L. gasseri (BC12, BC13), and L. vaginalis (BC16, BC17), did not result in cell depletion, as compared with control (Figure 1B, lower panel, BC5 representative of this group). In contrast, the colonization of tissue blocks by the remaining nine Lactobacillus strains, L. crispatus (BC1, BC4, BC6, BC7, BC8) and L. gasseri (BC9, $\mathrm{BC} 10, \mathrm{BC} 11, \mathrm{BC} 14)$, resulted in a loss of $\mathrm{T}\left(\mathrm{CD}^{+}\right)$cells as well as an increase in the expression of the apoptotic marker $\mathrm{Bcl} 2$ (data not shown). The losses of $\mathrm{CD}^{+}$cells were not characteristics of particular species of Lactobacillus, as some strains of L. crispatus, L. gasseri, and L. vaginalis induced cell depletion while others did not. Lactobacillus strains that induced $\mathrm{CD}^{+}$cell depletion were not used in further experiments.

\section{Lactobacillus-CM Inhibits HIV-1 Replication}

To investigate the effects of metabolites secreted by lactobacilli on HIV-1 replication in ex vivo tissues, tissue blocks were pre-incubated with Lactobacillus media conditioned by L. crispatus (BC3, BC5), L. gasseri (BC12, BC13), and L. vaginalis (BC16, BC17), infected with $\mathrm{HIV}-1$, and cultured as described in Section "Materials and Methods." In both cervico-vaginal and lymphoid tissues undiluted Lactobacillus$\mathrm{CM}$ suppressed replication of HIV-1 compared with the control by $91.9 \pm 4.3$ and $98.3 \pm 1.4 \%$ (L. crispatus BC3, $p<0.0001, n=5$ ), $95.9 \pm 4.8$ and $97.7 \pm 1.8 \%$ (L. crispatus $\mathrm{BC} 5, p<0.0001, n=5$ ), $93.5 \pm 3.6$ and $98.2 \pm 1.9 \%$ (L. gasseri BC12, $p<0.0001, n=5), 91.9 \pm 1.5$ and $98.3 \pm 2.3 \%$ (L. gasseri BC13, $p<0.0001, n=5$ ), $95.9 \pm 5.0$ and $98.1 \pm 2.9 \%$ (L. vaginalis $\mathrm{BC16}, p<0.0001, n=5), 85.8 \pm 11.7$ and $95.0 \pm 6.5 \%$ (L. vaginalis BC17, $p<0.0001, n=5$ ), respectively (Figure 2). Lactobacillus-CM had an inhibitory effect on HIV-1 replication even when diluted fivefold. Depending on the Lactobacillus strain, inhibition of HIV-1 replication by such 

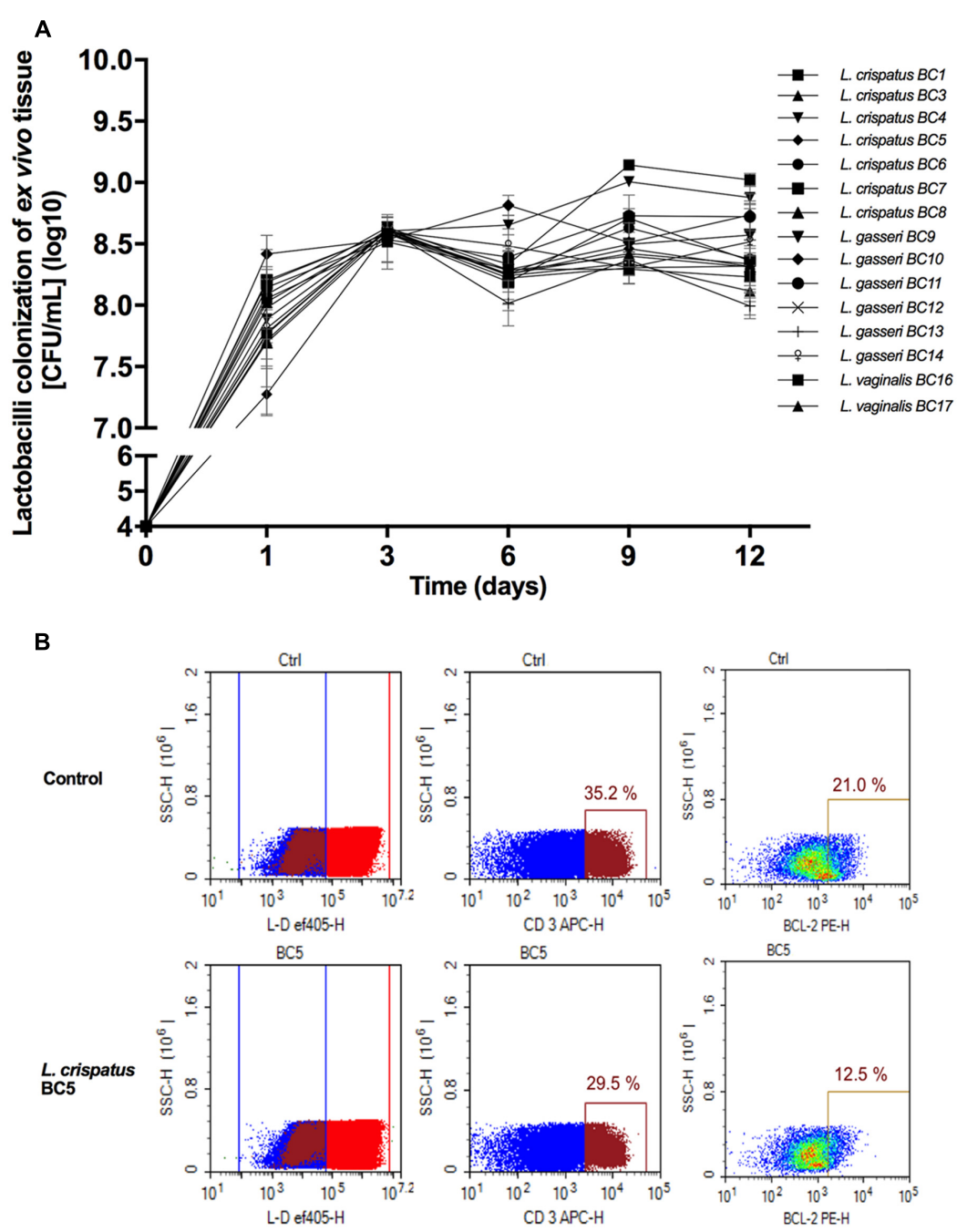

FIGURE 1 | Lactobacillus colonization of ex vivo tissue. (A) Tonsillar tissues were colonized with 15 vaginal Lactobacillus strains (L. crispatus BC1, BC3-BC8; L. gasseri BC9-BC14 and $L$. vaginalis BC16, BC17), at a starting inoculum of $10^{4} \mathrm{CFU} / \mathrm{mL}$ and cultured for 12 days. We evaluated Lactobacillus colonization every 3 days by measuring $\mathrm{OD}_{600}$ using a spectrophotometer. Bars represent mean $\pm \mathrm{SD}$ from tissues of three donors. (B) We evaluated tissue cell depletion induced by Lactobacillus colonization of ex vivo tissues 3 days after bacterial inoculation using flow cytometry. Panels (from left to right) represent live/dead staining, CD3 ${ }^{+}$ expression in live cells, and Bcl2 expression in $\mathrm{CD}^{+}$cells in control (upper row) and L. crispatus BC5-colonized tissue (lower row).

diluted medium was ranging from $44.3 \pm 31.7 \%$ (L. crispatus $\mathrm{BC} 3, p=0.0038, n=5$ ) to $77.3 \pm 7.3 \%$ (L. vaginalis $\mathrm{BC} 16$, $p<0.0001, n=5$ ) in cervico-vaginal tissue (Figure 2B) and from $55.5 \pm 13.2 \%$ (L. vaginalis BC17, $p<0.0001, n=5$ ) to $93.1 \pm 5.2 \%$ (L. crispatus BC5, $p=0.0001, n=5$ ) in tonsillar tissue (Figure 2D).

\section{Virucidal Capacity of Lactobacillus-CM against HIV-1}

In order to understand whether Lactobacillus-CM can suppress HIV-1 infectivity before interaction with tissues, we pre-incubated HIV-1 for $1 \mathrm{~h}$ with Lactobacillus-CM (diluted 1:5) and tested HIV-1 infectivity in cervico-vaginal tissues ex vivo. We studied the virucidal capacities of Lactobacillus-CM of six strains: L. crispatus (BC3, BC5), L. gasseri (BC12, BC13), and L. vaginalis (BC16, BC17). As shown in Figure 3A, HIV-1 replication was reduced when cervico-vaginal tissues were infected with HIV-1 pre-treated with Lactobacillus-CM from L. crispatus $\mathrm{BC} 3(47.7 \pm 7.0 \%, p=0.005, n=5)$, L. crispatus BC5 $(60.9 \pm 13.8 \%, p=0.0005, n=5)$, L. gasseri BC12 $(64.0 \pm 11.4 \%$, $p<0.0001, n=5$ ), and $L$. vaginalis BC16 (57.4 $\pm 8.1 \%$, $p=0.003, n=5$ ) (Figure 3B). No statistically significant inhibition was observed due to Lactobacillus-CM from L. gasseri $\mathrm{BC} 13(28.6 \pm 6.6 \%, p=0.13, n=5)$ and L. vaginalis $\mathrm{BC} 17$ $(31.1 \pm 24.8 \%, p=0.06, n=5)$.

\section{Effects of Lactic Acid and pH on HIV-1 Replication}

To investigate whether lactic acid produced by lactobacilli is responsible for HIV-1 inhibition, we measured the 


\section{Cervico-vaginal tissue}

A

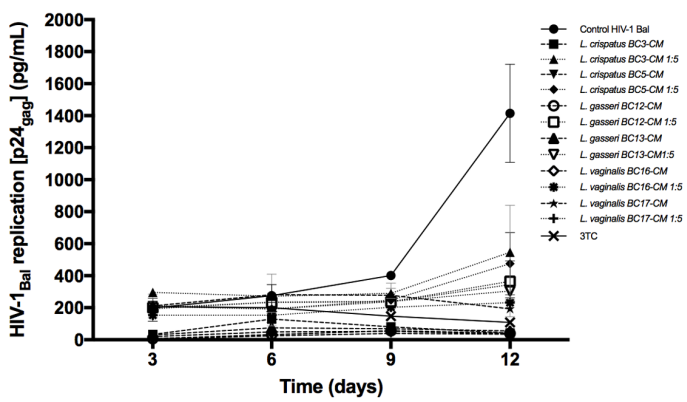

Tonsillar tissue

C

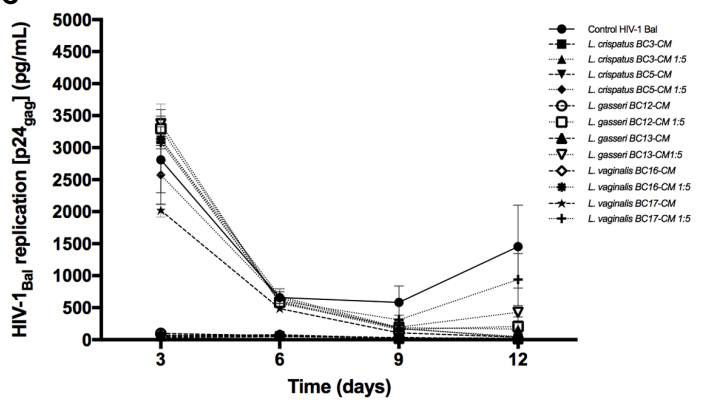

B

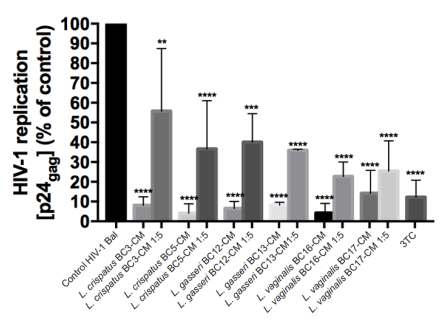

D

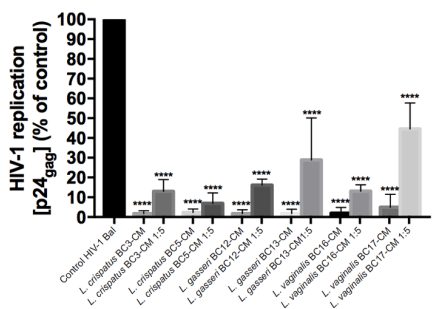

FIGURE 2 | HIV-1 infection of human tissue ex vivo treated with Lactobacillus-CM. Cervico-vaginal (A,B) and tonsillar (C,D) tissue blocks were pre-incubated with undiluted and diluted 1:5 Lactobacillus-CM from six strains (L. crispatus BC3 and BC5; L. gasseri BC12 and BC13; and L. vaginalis BC16 and $\mathrm{BC} 17)$. Tissue cultures were inoculated with HIV-1 and kept in the Lactobacillus-CM for 3 days. At day 3 , the Lactobacillus-CM was removed and cultures were kept in regular medium until day 12 post-inoculation. (A,C) We evaluated the kinetics of HIV-1 replication in tissues by measuring the levels of p24 gag in tissue culture medium. (B,D) Replication of HIV-1 in Lactobacillus-treated tissues expressed as percentages of HIV-1 replication in untreated control (black bars). Statistical significance vs. control is presented. Bars represent mean \pm SD from five tissue donors. Asterisks indicate statistical significance by one-way ANOVA multiple comparison $\left({ }^{*} p<0.05,{ }^{* *} p<0.01,{ }^{* * *} p<0.001,{ }^{* * * *} p<0.0001\right)$. 3TC (dideoxythiacytidine or lamivudine) at $10 \mu \mathrm{M}$ is a powerful HIV-1 inhibitor that we used in our study as a positive control.
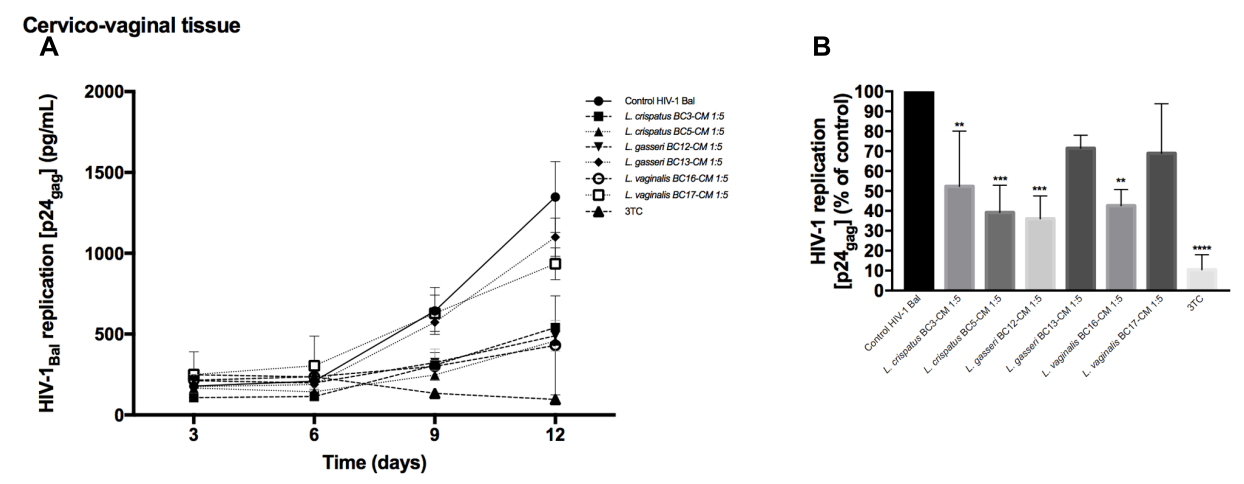

FIGURE 3 | Virucidal effect of Lactobacillus-CM against HIV-1. Virucidal capacities of six strains, L. crispatus (BC3 and BC5); L. gasseri (BC12 and BC13); and L. vaginalis (BC16, BC17) are presented. HIV-1 preparation was pretreated with Lactobacillus-CM diluted 1:5 for $1 \mathrm{~h}$, and HIV-1 infectivity was tested in cervico-vaginal tissues ex vivo. (A) We evaluated the kinetics of HIV-1 replication by measuring the levels of p24 gag in tissue culture medium. (B) Replication of HIV-1 in Lactobacillus-treated tissues expressed as percentages of HIV-1 replication in untreated control (black bars). Statistical significance vs. control is presented. Bars represent mean $\pm \mathrm{SD}$ from tissues of five patients. Asterisks indicate statistical significance by one-way ANOVA multiple comparison $\left({ }^{*} p<0.05,{ }^{* *} p<0.01\right.$, ${ }^{* * *} p<0.001,{ }^{* * *} p<0.0001$ ). 3TC (dideoxythiacytidine or lamivudine) at $10 \mu \mathrm{M}$ is a powerful HIV-1 inhibitor that we used in our study as a positive control.

concentrations of lactic acid isomers D and L in LactobacillusCM (Table 1). Depending on the strain, the concentrations of lactic acid isomers $\mathrm{D}$ and $\mathrm{L}$ ranged from 1.8 to $3.6 \mathrm{mM}$ and from 9.0 to $24.7 \mathrm{mM}$, respectively. L. gasseri $\mathrm{BC} 12$ was the strain that produced the highest concentrations of both isomers, while L. crispatus BC17 was the strain that produced the lowest 
TABLE 1 | Lactic acid isomers $\mathrm{D}$ and $\mathrm{L}$ and $\mathrm{pH}$ in Lactobacillus-CM.

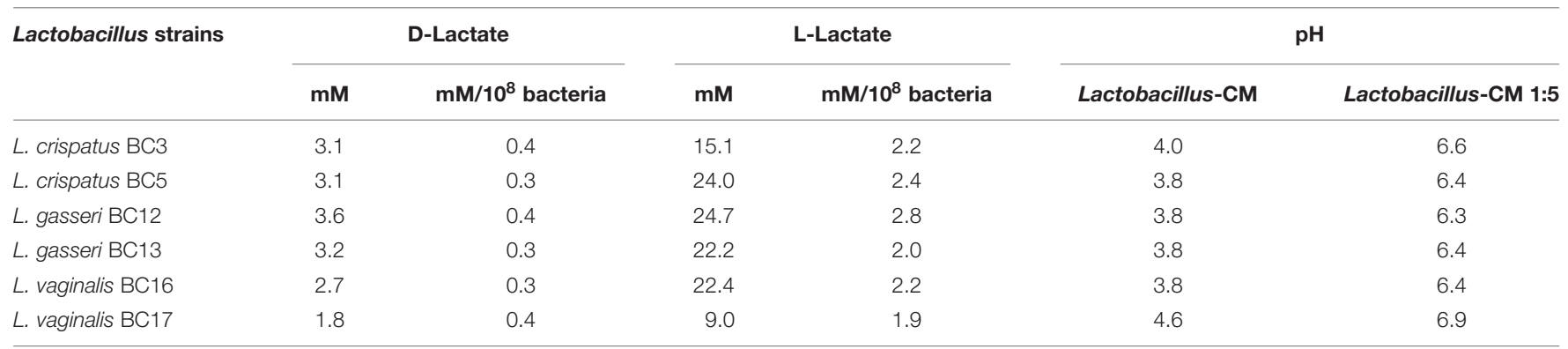
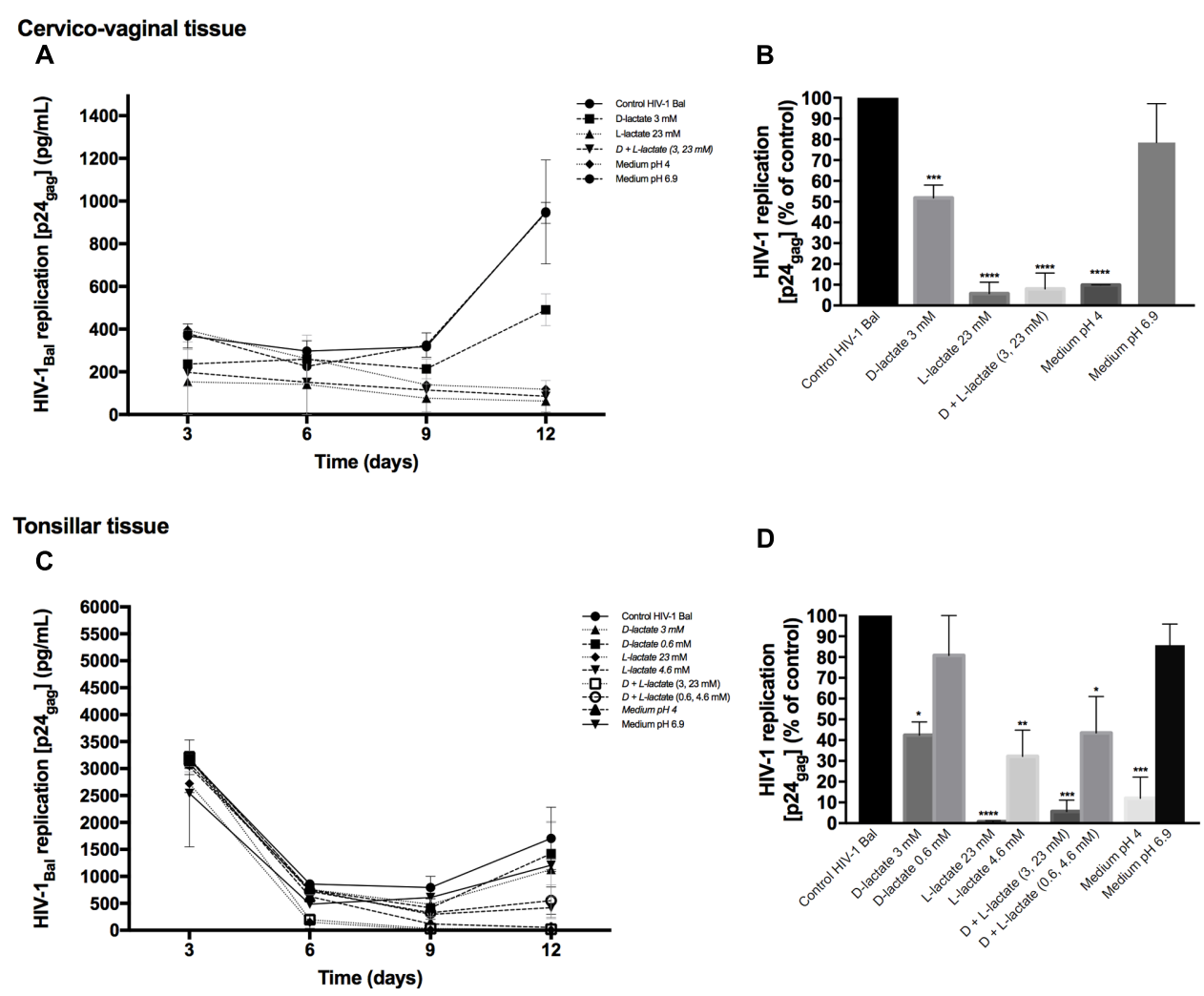

D

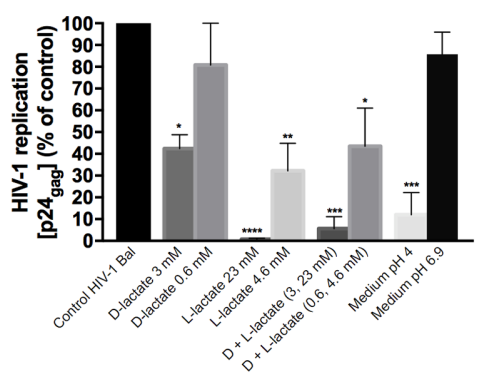

FIGURE 4 | Effect of lactic acid isomers $D$ and $L$ and of $p H$ on HIV-1 replication. The effects of lactate isomers $D$ and $L$ at concentrations found in Lactobacillus-CM on HIV-1 replication were tested in cervico-vaginal $(\mathbf{A}, \mathbf{B})$ and tonsillar $(\mathbf{C}, \mathbf{D})$ tissues. Isomers $D$ and $L$ were respectively tested at 3 and $23 \mathrm{mM}$ concentrations, which correspond to the average concentrations of lactic acid found in Lactobacillus-CM. The mixture of isomers $L$ and $D$ was tested at the concentrations of 3 and $23 \mathrm{mM}$. We evaluated the effect of acidic $\mathrm{pH}$ on HIV-1 infectivity in ex vivo tissues by buffering the culture medium at pH 4 and $\mathrm{pH} 6.9$ using $\mathrm{HCl}$. (A,C) We evaluated the kinetics of HIV-1 replication in tissues by measuring the levels of p24gag in culture medium. (B,D) Replication of HIV-1 in Lactobacillus-treated tissues was expressed as percentage of HIV-1 replication in untreated control (black bars). Statistical significance vs. control is presented. Bars represent mean $\pm \mathrm{SD}$ from tissues of three to five donors. Asterisks indicate statistical significance by one-way ANOVA multiple comparison $\left({ }^{*} p<0.05,{ }^{* *} p<0.01\right.$, $\left.{ }^{* * *} p<0.001,{ }^{* * * *} p<0.0001\right)$.

concentrations. Next, we tested the effects of lactic acid isomers at the concentration found in undiluted Lactobacillus-CM or CM diluted 1:5 on HIV-1 replication in tissues ex vivo (Figure 4). As shown in Figures 4A,C, lactic acid isomers D (3 $\mathrm{mM}), \mathrm{L}(23 \mathrm{mM})$, and $\mathrm{D}+\mathrm{L}(3 ; 23 \mathrm{mM})$ significantly reduced HIV-1 replication in both cervico-vaginal and tonsillar tissues. We found that D lactate $(3 \mathrm{mM})$ inhibited HIV-1 replication by $48.2 \pm 6.2 \%$ in cervico-vaginal $(p=0.0004, n=3)$ and by $57.6 \pm 33.2 \%$ in tonsillar ( $p=0.0125, n=3$ ) tissue cultures, while
L lactate $(23 \mathrm{mM})$ suppressed HIV-1 replication by $94.3 \pm 5.5 \%$ $(p<0.0001, n=3)$ and by $99.3 \pm 21.9 \%(p<0.0001, n=3)$ in cervico-vaginal and tonsillar tissues, respectively. The mixture of $\mathrm{D}+\mathrm{L}$ lactate suppressed HIV-1 replication by $92.1 \pm 7.7 \%$ in cervico-vaginal and by $94.4 \pm 30.4 \%$ in tonsillar tissue $(p<0.0001, n=3)$ (Figures 4B,D). Afterward, we evaluated the effect of lactic acid isomers at the concentrations found in fivefold-diluted Lactobacillus-CM on HIV-1 replication in lymphoid tissue (Figures $4 \mathbf{C , D}$ ). We found that isomer D did 
not inhibit HIV-1 replication while isomer $\mathrm{L}$ and the mixture of isomers $\mathrm{D}+\mathrm{L}$ significantly reduced HIV-1 replication in tonsillar tissues by $67.8 \pm 0.8 \%$ (isomer $\mathrm{L}, p=0.0033, n=3$ ) and by $56.5 \pm 9.5 \%$ (isomers $\mathrm{D}+\mathrm{L}, p=0.0142, n=3$ ) (Figure $4 \mathrm{D}$ ).

Furthermore, we evaluated whether the effect of lactobacilli on HIV-1 replication is due to the acidic $\mathrm{pH}$ of the Lactobacillus-CM. As shown in Table 1, $\mathrm{pH}$ values of undiluted Lactobacillus-CM ranged from 3.8 to 4.6 and of fivefold-diluted LactobacillusCM from 6.3 to 6.9. To mimic the effect of $\mathrm{pH}$ on HIV-1 replication, we acidified the culture medium of human cervicovaginal and tonsillar tissues with $\mathrm{HCl}$. In the culture medium buffered to $\mathrm{pH} 4$, HIV-1 replication was reduced in both cervicovaginal $(90.1 \pm 0.1 \%, p<0.0001, n=3)$ and tonsillar tissue (88.0 $\pm 17.5 \%, p=0.0003, n=3$ ) compared with control tissue blocks cultured in regular medium (Figures 4B,D). No statistically significant inhibition of HIV-1 replication in cervicovaginal or tonsillar tissues was observed when the culture medium was buffered to $\mathrm{pH} 6.9(21.6 \pm 18.8 \%, p=0.1492, n=2$ and $14.28 \pm 10.19 \%, p=0.9, n=3$, respectively).

\section{Virucidal Capacity of Lactobacillus Cells against HIV-1}

In order to understand if vaginal Lactobacillus themselves are able to suppress HIV-1 infectivity, the virucidal capacities of six strains, L. crispatus (BC3, BC5), L. gasseri (BC12, BC13), and $L$. vaginalis (BC16, BC17), were studied. HIV-1 was first incubated with Lactobacillus-CP, and after bacteria have been washed off, the infectivity of HIV-1 was tested in cervicovaginal tissues ex vivo, as described in Section "Materials and Methods." As shown in Figure 5A, tissue infection with HIV-1 pre-incubated with Lactobacillus-CP for $1 \mathrm{~h}$ resulted in inhibition of HIV-1 replication by $64.7 \pm 14.9 \%$ for $L$. crispatus BC5 $(p<0.0001, n=5)$, by $39.3 \pm 18.4 \%$ for L. gasseri $\mathrm{BC} 12$ $(p=0.0124, n=5)$, and by $59.8 \pm 13.2 \%$ for L. vaginalis $\mathrm{BC} 17$ $(p=0.0002, n=5)$. No statistically significant inhibition was observed with $L$. crispatus BC3 (19.4 $\pm 18.5 \%, p=0.46, n=5)$, L. gasseri BC13 (16.1 $\pm 27.9 \%, p=0.64, n=5)$, and L. vaginalis $\mathrm{BC} 16(9.0 \pm 15.6 \%, p=0.96, n=5)$ (Figure 5B).

Thereafter, to investigate whether this suppression of HIV-1 replication of cervico-vaginal tissue by $L$. crispatus $\mathrm{BC} 5, L$. gasseri $\mathrm{BC} 12$, and L. vaginalis $\mathrm{BC} 17$ in the above-described experiments was due to viral binding to Lactobacillus cells, we measured the concentration of $\mathrm{p} 24_{\mathrm{gag}}$ on Lactobacillus-CP after bacteria were separated by centrifugation. We found that these three strains adsorbed $36.2 \pm 21.5,29.6 \pm 25.6$, and $39.2 \pm 9.6 \%$ of HIV-1, respectively, as evaluated from measurements of $\mathrm{p} 24_{\mathrm{gag}}$ (Figure 5C). In the CP of the remaining strains (L. crispatus BC3, L. gasseri $\mathrm{BC} 13$, and L. vaginalis $\mathrm{BC} 16)$ the $\mathrm{p} 24_{\text {gag }}$ was less than $10 \%$ of the original HIV-1 preparation (data not shown).

\section{DISCUSSION}

The human female genital tract is normally colonized by a vast number of microorganisms collectively referred to as the vaginal microbiota (Petrova et al., 2015). Although minor variations depending on age, menstruation, sexual activity, use of medication, hygiene practice, etc. (Srinivasan and Fredricks, 2008) may affect the vaginal microbiota, healthy women of reproductive age are generally dominated by Lactobacillus species (Pavlova et al., 2002; Hyman et al., 2005; Ravel et al., 2011). A Lactobacillus-dominated microbiota appears to be a biomarker for a healthy vaginal ecosystem, as changes in the vaginal microbiota, especially shifting away from Lactobacillus dominance, are associated with bacterial vaginosis and increased risks of acquisition of sexually transmitted infections (Cherpes et al., 2003; Wiesenfeld et al., 2003), in particular HIV (Taha et al., 1998; Atashili et al., 2008; Nardis et al., 2013; Mirmonsef and Spear, 2014; Petrova et al., 2015; Gosmann et al., 2017). Several mechanisms have been suggested to explain the protective role of Lactobacillus against HIV as well as the increased risk of HIV acquisition in the background of bacterial vaginosis, but all these mechanisms remain to be substantiated (Petrova et al., 2013). The vaginal microbiota seems to protect against HIV directly, by production of antiviral compounds (lactic acid, hydrogen peroxide, bacteriocins, and lectin molecules), or indirectly, stimulating immune responses or inhibiting colonization of microorganisms that cause bacterial vaginosis (Petrova et al., 2013, 2015). Ex vivo models may contribute to decipherment and substantiation of these mechanisms under controlled laboratory conditions.

Here, we investigated some of these mechanisms by studying the effects of vaginal lactobacilli on HIV-1 in the context of human cervico-vaginal and tonsillar tissues ex vivo (Saba et al., 2010; Merbah et al., 2011; Introini et al., 2014). These human tissue cultures offer major advantages over single-cell cultures, as they retain general tissue cytoarchitecture and important functional aspects of cell-cell interactions (Grivel and Margolis, 2009). Therefore, they remain a model of choice to study host-pathogen interactions (reviewed in Grivel and Margolis, 2009). These ex vivo tissues have proved to be useful in studies of the effect of HIV-1 copathogens on HIV-1 replication (Grivel et al., 2001; Lisco et al., 2007; Vanpouille et al., 2007) as well as in pre-clinical drug testing (Andrei et al., 2011; Vanpouille et al., 2012). Cervico-vaginal tissue ex vivo is a more adequate system than tonsillar tissues to study LactobacillusHIV-1 interactions, since in vivo human tonsillar tissues do not come into contact with lactobacilli. Nevertheless, we used not only cervico-vaginal but also tonsillar tissues, because the latter are typical lymphoid tissue, where critical events in HIV transmission and infection occur in vivo. Also, tonsils are more accessible and unlike cervical tissues are supplied in amounts needed to compare the effects of multiple strains of lactobacilli on HIV-1 in the same donor tissue. It is important that our results were similar for both cervico-vaginal and tonsillar tissues.

Earlier, an ex vivo model of porcine vaginal mucosa was used to investigate the mechanistic role of Lactobacillus species in colonization by Gardnerella vaginalis and $N$. gonorrhoeae (Breshears et al., 2015). Although the porcine vaginal mucosa system offered advantages over single-cell cultures, it may not reflect important features of the human system, in particular those of human mucosal epithelia, which are crucial for interactions of HIV with other pathogens. 

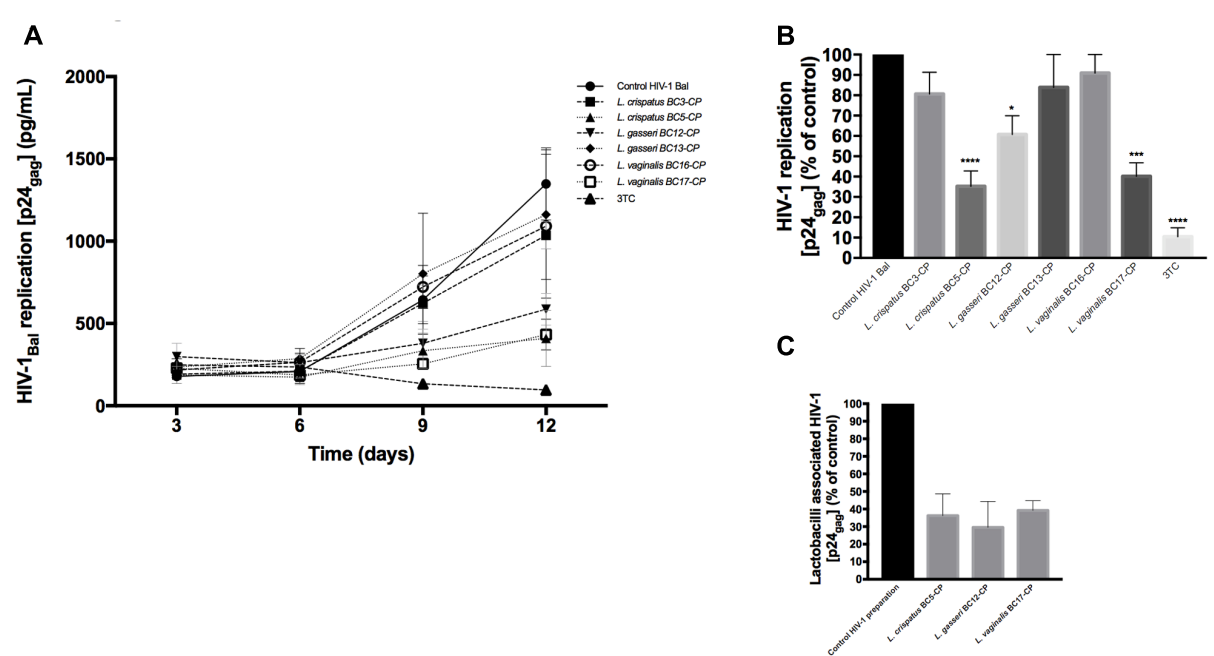

FIGURE 5 | Virucidal effect of Lactobacillus against HIV-1. Virucidal capacity of six strains, L. crispatus (BC3, BC5), L. gasseri (BC12, BC13), and L. vaginalis (BC16, BC17) is presented. HIV-1 was pre-treated with Lactobacillus-CP at $10^{8} \mathrm{CFU} / \mathrm{mL}$, and HIV-1 infectivity was then tested in cervico-vaginal tissues ex vivo. (A) We evaluated HIV-1 replication kinetics in tissues by measuring p24gag in culture medium. (B) Replication of HIV-1 in Lactobacillus-treated tissues was expressed as percentage of HIV-1 replication in untreated control (black bars). (C) Fractions of p24gag associated with CP after incubation with HIV-1 are presented. Statistical significance vs. control was calculated. Bars represent mean \pm SD from five patients. Asterisks indicate statistical significance by one-way ANOVA multiple comparison $\left({ }^{*} p<0.05,{ }^{* *} p<0.01,{ }^{* * *} p<0.001,{ }^{* * * *} p<0.0001\right)$. 3TC (dideoxythiacytidine or lamivudine) at $10 \mu \mathrm{M}$ is a powerful HIV-1 inhibitor that we used in our study as a positive control.

To address the effects of lactobacilli on HIV-1 infection in the context of human tissues, we first colonized them ex vivo with 15 different strains of Lactobacillus that were isolated from vaginal swabs of healthy premenopausal women. These strains have been characterized for their activity against Candida, C. trachomatis, and urogenital/intestinal bacteria (Parolin et al., 2015; Nardini et al., 2016; Siroli et al., 2017).

In the present work, we found that all lactobacilli colonized and grew in human tissues ex vivo to densities comparable with those observed in vaginal specimens (Antonio et al., 2009; Aleshkin et al., 2011). Tissue colonization with some of the tested bacterial strains resulted in the depletion of T cells. Although this phenomenon may be relevant to the protection against HIV-1 in vivo, we focused our study on six strains of Lactobacillus (L. crispatus $\mathrm{BC} 3, \mathrm{BC} 5$; L. gasseri $\mathrm{BC} 12, \mathrm{BC} 13$; and L. vaginalis $\mathrm{BC} 16, \mathrm{BC} 17)$ that did not deplete cells in tissue. We found that all these lactobacilli efficiently suppressed HIV-1 replication in human tissues ex vivo, and we investigated the mechanisms of this phenomenon.

First, we investigated whether lactobacilli release suppressive factors that inhibit HIV-1 replication in human tissues ex vivo. We found that they do indeed release factors that suppress HIV-1 replication, since the CM inhibited $\mathrm{HIV}-1$ replication in human cervico-vaginal and tonsillar tissues.

Although such a medium may contain multiple inhibitory factors, we first focused on two of them; $\mathrm{pH}$ and lactic acid, whose roles in suppressing HIV infection were suggested earlier (Martin et al., 1985; Ongradi et al., 1990; O’Connor et al., 1995; Aldunate et al., 2013). Depending on the bacterial strain, the $\mathrm{pH}$ of Lactobacillus-CM varied from 3.8 to 4.6. We adjusted the $\mathrm{pH}$ of the tissue culture to these $\mathrm{pH}$ values, and in agreement with earlier studies (Martin et al., 1985; Ongradi et al., 1990; Ravel et al., 2011) we found that this acidification may be directly responsible for HIV-1 inhibition. Low $\mathrm{pH}(<4.5)$ is typical for the vaginal ecosystems in vivo that are dominated by Lactobacillus species in healthy women (Fox et al., 1973; Boskey et al., 1999; O’Hanlon et al., 2013). However, during vaginal intercourse, vaginal fluid is diluted by HIV-containing semen, resulting in neutral $\mathrm{pH}$ (Tevi-Benissan et al., 1997). Also, in the presence of vaginal dysbiosis (i.e., bacterial vaginosis), vaginal $\mathrm{pH}$ increases (Onderdonk et al., 2016). Therefore, in our experiments we diluted $\mathrm{CM}$ with normal media, resulting in a $\mathrm{pH}$ between 6.3 and 6.9; this diluted CM was still inhibitory for HIV-1 replication in human tissue ex vivo. Control experiments with $\mathrm{pH}$ 6.9 demonstrated no HIV-1 suppression, suggesting that other factors beyond lowered $\mathrm{pH}$ may also be important for HIV-1 inhibition, at least for some of the lactobacilli.

One such factor considered in the literature is the major Lactobacillus metabolite lactic acid (O'Hanlon et al., 2011, 2013). The importance of this metabolite is evidenced by the fact that in our experiments we observed a correlation between the capacity of supernatant of lactobacilli to inhibit HIV-1 replication and the capacity of lactobacilli to produce lactic acid. Therefore, we investigated the effect of lactic acid isomers D and L on HIV-1 infection. We found that the addition of these isomers to tissue culture medium at concentrations that corresponded to their amounts released by lactobacilli resulted in HIV-1 inhibition. In our work, the racemic lactic acid in Lactobacillus-CM ranged from 10.8 to $28.3 \mathrm{mM}$ and thus was not higher than the physiological level, reported to be around $110 \mathrm{mM}$ (O'Hanlon et al., 2013). The protective effect of lactic acid in our ex vivo tissue system is in agreement with the work of Nunn et al. (2015), 
who reported that a high concentration of lactic acid in cervicovaginal mucus plays an important role in protection against HIV-1 and other sexually transmitted infections. We found that the $\mathrm{L}$ isomer rather than the $\mathrm{D}$ isomer was predominantly responsible for HIV-1 inhibition. These results indicated that lactic acid, in particular its L isomer, inhibited HIV-1 replication, independently from lowering the $\mathrm{pH}$. Similarly, antibacterial properties of lactic acid against Escherichia coli, demonstrated earlier, were also ascribed predominantly to the $\mathrm{L}$ isomer (McWilliam Leitch and Stewart, 2002).

Next, we investigated whether Lactobacillus could have a direct virucidal effect on HIV-1. To answer this question, we incubated an HIV-1 preparation in Lactobacillus-CM and then tested HIV-1 infectivity in human tissue culture. We found that HIV-1 infectivity in cervico-vaginal tissue was significantly reduced. We previously reported similar findings when testing the effect of Lactobacillus-CM on C. trachomatis (Nardini et al., 2016). Finally, we investigated whether direct interactions with lactobacilli may affect HIV-1. We found that a significant fraction of virions is adsorbed on bacteria. These virucidal effects of lactobacilli may be relevant to the inhibition of HIV-1 transmission in vivo.

In general, the level of HIV-1 suppression may depend on the superimposition of multiple mechanisms, different for each Lactobacillus strain. These mechanisms include change of $\mathrm{pH}$, production of lactic acid, HIV adsorption on the surface of lactobacilli, etc. However, lactic acid produced by lactobacilli in the context of human tissues ex vivo seems to be a major cause of HIV-1 inhibition.

Several molecular mechanisms by which this metabolite may affect HIV-1 have been suggested. It was reported that lactic acid could disrupt cellular membranes (Alakomi et al., 2000), acidify cytosol (Russell and Diez-Gonzalez, 1998), unfold proteins (Tang et al., 2003), and inhibit enzymatic activity (McWilliam Leitch and Stewart, 2002). Any of these reported effects of lactic acid might be sufficient to suppress HIV infection, e.g., by destroying the viral envelope, unfolding gp120, and/or inhibiting HIV enzymes involved in the HIV cycle (Aldunate et al., 2013).

Like any other models, our model of human tissue has some limitations, e.g., lack of tissue polarization and limited tissue survival ( $\sim 3$ weeks). In the context of this study, a significant

\section{REFERENCES}

Alakomi, H. L., Skytta, E., Saarela, E. M., Mattila-Sandholm, T., Latva-Kala, K., and Helander, I. M. (2000). Lactic acid permeabilizes gram-negative bacteria by disrupting the outer membrane. Environ. Microbiol. 66, 2001-2005. doi: 10.1128/AEM.66.5.2001-2005.2000

Aldunate, M., Tyssen, D., Johnson, A., Zakir, T., Sonza, S., Moench, T., et al. (2013). Vaginal concentrations of lactic acid potently inactivate HIV. J. Antimicrob. Chemother. 68, 2015-2025. doi: 10.1093/jac/dkt156

Aleshkin, V. A., Voropaeva, E. A., and Shenderov, B. A. (2011). Vaginal microbiota in healthy women and patients with bacterial vaginosis and nonspecific vaginitis. Microb. Ecol. Health Dis. 18, 71-74. doi: 10.3402/mehd.v18i2.7694

Andrei, G., Lisco, A., Vanpouille, C., Introini, A., Balestra, E., van den Oord, J., et al. (2011). Topical tenofovir, a microbicide effective against HIV, inhibits herpes simplex virus-2 replication. Cell Host Microbe 10, 379-389. doi: 10.1016/j.chom. 2011.08.015 limitation was that we were not able to maintain in tissue cultures both lactobacilli and HIV-1 simultaneously, since HIV-1 requires aerobic while lactobacilli require anaerobic conditions. Therefore, in tissue culture experiments, we investigated the effect of Lactobacillus-CM on HIV-1.

Extrapolated to in vivo, our results may explain why the presence of normal vaginal microbiota, which include multiple species of Lactobacillus, is associated with a decreased risk of HIV acquisition in uninfected women (Atashili et al., 2008) and with lower HIV genital shedding in infected women (Sha et al., 2005; Spear et al., 2008; Mitchell et al., 2013).

The positive effects of lactobacilli on the health of the female genital tract are generating increasing interest in their use in probiotic formulations for the prophylaxis and therapy of several vaginal disturbances (Reid et al., 2001; Burton et al., 2003; Donders et al., 2010). Also, live recombinant lactobacilli releasing anti-HIV compounds have been suggested as a new therapeutic approach and successfully tested in macaques (Lagenaur et al., 2011; Brichacek et al., 2013). Further studies are needed to evaluate the potential of altering the spectra of vaginal microbiota and/or the concentrations of vaginal components such as lactic acid (Decena et al., 2006) as effective strategies to enhance vaginal health. Human tissues ex vivo may serve as a test system for these strategies.

\section{AUTHOR CONTRIBUTIONS}

$\mathrm{RN}, \mathrm{SZ}, \mathrm{CV}, \mathrm{BV}$, and LM designed and performed the experiments, analyzed the data, and wrote the manuscript. All the authors contributed to data interpretation. All the authors read, reviewed, and approved the final manuscript.

\section{FUNDING}

This study was supported by the NICHD Intramural Program. We thank the entire staff of the Department of Pathology of Children's National Medical Center for their generous assistance in obtaining human tonsillar tissues.

Antonio, M. A., Meyn, L. A., Murray, P. J., Busse, B., and Hillier, S. L. (2009). Vaginal colonization by probiotic Lactobacillus crispatus CTV-05 is decreased by sexual activity and endogenous Lactobacilli. J. Infect. Dis. 199, 1506-1513. doi: 10.1086/598686

Atashili, J., Poole, C., Ndumbe, P. M., Adimora, A. A., and Smith, J. S. (2008). Bacterial vaginosis and HIV acquisition: a meta-analysis of published studies. AIDS 22, 1493-1501. doi: 10.1097/QAD.0b013e3283021a37

Biancotto, A., Brichacek, B., Chen, S. S., Fitzgerald, W., Lisco, A., Vanpouille, C., et al. (2009). A highly sensitive and dynamic immunofluorescent cytometric bead assay for the detection of HIV-1 p24. J. Virol. Methods 157, 98-101. doi: 10.1016/j.jviromet.2008.11.013

Boskey, E. R., Telsch, K. M., Whaley, K. J., Moench, T. R., and Cone, R. A. (1999). Acid production by vaginal flora in vitro is consistent with the rate and extent of vaginal acidification. Infect. Immun. 67, 5170-5175.

Breshears, L. M., Edwards, V. L., Ravel, J., and Peterson, M. L. (2015). Lactobacillus crispatus inhibits growth of Gardnerella vaginalis and Neisseria gonorrhoeae on 
a porcine vaginal mucosa model. BMC Microbiol. 15:276. doi: 10.1186/s12866015-0608-0

Brichacek, B., Lagenaur, L. A., Lee, P. P., Venzon, D., and Hamer, D. H. (2013). In vivo evaluation of safety and toxicity of a Lactobacillus jensenii producing modified cyanovirin-N in a rhesus macaque vaginal challenge model. PLoS ONE 8:e78817. doi: 10.1371/journal.pone.0078817

Burton, J. P., Cadieux, P. A., and Reid, G. (2003). Improved understanding of the bacterial vaginal microbiota of women before and after probiotic instillation. Appl. Environ. Microbiol. 69, 97-101. doi: 10.1128/AEM.69.1.97-101.2003

Cherpes, T. L., Meyn, L. A., Krohn, M. A., Lurie, J. G., and Hillier, S. L. (2003). Association between acquisition of herpes simplex virus type 2 in women and bacterial vaginosis. Clin. Infect. Dis. 37, 319-325. doi: 10.1086/375819

Decena, D. C., Co, J. T., Manalastas, R. M. Jr., Palaypayon, E. P., Padolina, C. S., Sison, J. M., et al. (2006). Metronidazole with Lactacyd vaginal gel in bacterial vaginosis. J. Obstet. Gynaecol. Res. 32, 243-251. doi: 10.1111/j.1447-0756.2006. 00383.x

Donders, G. G., Van Bulck, B., Van de Walle, P., Kaiser, R. R., Pohlig, G., Gonser, S., et al. (2010). Effect of lyophilized lactobacilli and $0.03 \mathrm{mg}$ estriol (Gynoflor(R)) on vaginitis and vaginosis with disrupted vaginal microflora: a multicenter, randomized, single-blind, active-controlled pilot study. Gynecol. Obstet. Invest. 70, 264-272. doi: 10.1159/000314016

Fox, C. A., Meldrum, S. J., and Watson, B. W. (1973). Continuous measurement by radio-telemetry of vaginal pH during human coitus. J. Reprod. Fertil. 33, 69-75. doi: 10.1530/jrf.0.0330069

Gosmann, C., Anahtar, M. N., Handley, S. A., Farcasanu, M., Abu-Ali, G., Bowman, B. A., et al. (2017). Lactobacillus-deficient cervicovaginal bacterial communities are associated with increased hiv acquisition in young south african women. Immunity 46, 29-37. doi: 10.1016/j.immuni.2016.12.013

Grivel, J. C., Ito, Y., Faga, G., Santoro, F., Shaheen, F., Malnati, M. S., et al. (2001). Suppression of CCR5- but not CXCR4-tropic HIV-1 in lymphoid tissue by human herpesvirus 6. Nat. Med. 7, 1232-1235. doi: 10.1038/nm11011232

Grivel, J. C., and Margolis, L. (2009). Use of human tissue explants to study human infectious agents. Nat. Protoc. 4, 256-269. doi: 10.1038/nprot.2008.245

Hyman, R. W., Fukushima, M., Diamond, L., Kumm, J., Giudice, L. C., and Davis, R. W. (2005). Microbes on the human vaginal epithelium. Proc. Natl. Acad. Sci. U.S.A. 102, 7952-7957. doi: 10.1073/pnas.0503236102

Introini, A., Vanpouille, C., Grivel, J. C., and Margolis, L. (2014). An ex vivo Model of HIV-1 infection in human lymphoid tissue and cervico-vaginal Tissue. Bio Protoc. 4:e1047. doi: 10.21769/BioProtoc.1047

Kaewsrichan, J., Peeyananjarassri, K., and Kongprasertkit, J. (2006). Selection and identification of anaerobic lactobacilli producing inhibitory compounds against vaginal pathogens. FEMS Immunol. Med. Microbiol. 48, 75-83. doi: 10.1111/j. 1574-695X.2006.00124.x

Lagenaur, L. A., Sanders-Beer, B. E., Brichacek, B., Pal, R., Liu, X., Liu, Y., et al. (2011). Prevention of vaginal SHIV transmission in macaques by a live recombinant Lactobacillus. Mucosal Immunol. 4, 648-657. doi: 10.1038/mi. 2011.30

Lisco, A., Grivel, J. C., Biancotto, A., Vanpouille, C., Origgi, F., Malnati, M. S., et al. (2007). Viral interactions in human lymphoid tissue: human herpesvirus 7 suppresses the replication of CCR5-tropic human immunodeficiency virus type 1 via CD4 modulation. J. Virol. 81, 708-717. doi: 10.1128/JVI.01367-06

Martin, L. S., McDougal, J. S., and Loskoski, S. L. (1985). Disinfection and inactivation of the human T lymphotropic virus type III/Lymphadenopathyassociated virus. J. Infect. Dis. 152, 400-403. doi: 10.1093/infdis/152.2.400

McWilliam Leitch, E. C., and Stewart, C. S. (2002). Susceptibility of Escherichia coli $\mathrm{O} 157$ and non-O157 isolates to lactate. Lett. Appl. Microbiol. 35, 176-180. doi: 10.1046/j.1472-765X.2002.01164.x

Merbah, M., Introini, A., Fitzgerald, W., Grivel, J. C., Lisco, A., Vanpouille, C., et al. (2011). Cervico-vaginal tissue ex vivo as a model to study early events in HIV-1 infection. Am. J. Reprod. Immunol. 65, 268-278. doi: 10.1111/j.1600-0897.2010. 00967.x

Mirmonsef, P., and Spear, G. T. (2014). The barrier to HIV transmission provided by genital tract Lactobacillus colonization. Am. J. Reprod. Immunol. 71, 531-536. doi: 10.1111/aji.12232

Mitchell, C., Balkus, J. E., Fredricks, D., Liu, C., McKernan-Mullin, J., Frenkel, L. M., et al. (2013). Interaction between lactobacilli, bacterial vaginosisassociated bacteria, and HIV Type 1 RNA and DNA Genital shedding in U.S. and Kenyan women. AIDS Res. Hum. Retrovir. 29, 13-19. doi: 10.1089/AID. 2012.0187

Nardini, P., Nahui Palomino, R. A., Parolin, C., Laghi, L., Foschi, C., Cevenini, R., et al. (2016). Lactobacillus crispatus inhibits the infectivity of Chlamydia trachomatis elementary bodies, in vitro study. Sci. Rep. 6:29024. doi: 10.1038/ srep29024

Nardis, C., Mosca, L., and Mastromarino, P. (2013). Vaginal microbiota and viral sexually transmitted diseases. Ann. Ig. 25, 443-456. doi: 10.7416/ai.2013.1946

Nunn, K. L., Wang, Y. Y., Harit, D., Humphrys, M. S., Ma, B., Cone, R., et al. (2015). Enhanced trapping of HIV-1 by human cervicovaginal mucus is associated with Lactobacillus crispatus-dominant microbiota. MBio 6:e1084-15. doi: 10.1128/ mBio.01084-15

O'Connor, T. J., Kinchington, D., Kangro, H. O., and Jeffries, D. J. (1995). The activity of candidate virucidal agents, low $\mathrm{pH}$ and genital secretions against HIV-1 in vitro. Int. J. STD AIDS 6, 267-272. doi: 10.1177/095646249500600409

O'Hanlon, D. E., Moench, T. R., and Cone, R. A. (2011). In vaginal fluid, bacteria associated with bacterial vaginosis can be suppressed with lactic acid but not hydrogen peroxide. BMC Infect. Dis. 11:200. doi: 10.1186/1471-2334-11-200

O'Hanlon, D. E., Moench, T. R., and Cone, R. A. (2013). Vaginal pH and microbicidal lactic acid when lactobacilli dominate the microbiota. PLoS ONE 8:e80074. doi: 10.1371/journal.pone.0080074

Onderdonk, A. B., Delaney, M. L., and Fichorova, R. N. (2016). The human microbiome during bacterial vaginosis. Clin. Microbiol. Rev. 29, 223-238. doi: 10.1128/CMR.00075-15

Ongradi, J., Ceccherini-Nelli, L., Pistello, M., Specter, S., and Bendinelli, M. (1990). Acid sensitivity of cell-free and cell-associated HIV-1: clinical implications. AIDS Res. Hum. Retrovir. 6, 1433-1436. doi: 10.1089/aid.1990.6.1433

Parolin, C., Marangoni, A., Laghi, L., Foschi, C., Nahui Palomino, R. A., Calonghi, N., et al. (2015). Isolation of vaginal lactobacilli and characterization of anti-candida activity. PLOS ONE 10:e131220. doi: 10.1371/journal.pone. 0131220

Pavlova, S. I., Kilic, A. O., Kilic, S. S., So, J. S., Nader-Macias, M. E., Simoes, J. A., et al. (2002). Genetic diversity of vaginal lactobacilli from women in different countries based on 16S rRNA gene sequences. J. Appl. Microbiol. 92, 451-459. doi: 10.1046/j.1365-2672.2002.01547.x

Petrova, M. I., Lievens, E., Malik, S., Imholz, N., and Lebeer, S. (2015). Lactobacillus species as biomarkers and agents that can promote various aspects of vaginal health. Front. Physiol. 6:81. doi: 10.3389/fphys.2015.00081

Petrova, M. I., van den Broek, M., Balzarini, J., Vanderleyden, J., and Lebeer, S. (2013). Vaginal microbiota and its role in HIV transmission and infection. FEMS Microbiol. Rev. 37, 762-792. doi: 10.1111/1574-6976.12029

Ravel, J., Gajer, P., Abdo, Z., Schneider, G. M., Koenig, S. S., McCulle, S. L., et al. (2011). Vaginal microbiome of reproductive-age women. Proc. Natl. Acad. Sci. U.S.A. 108(Suppl. 1), 4680-4687. doi: 10.1073/pnas.1002611107

Redondo-Lopez, V., Cook, R. L., and Sobel, J. D. (1990). Emerging role of lactobacilli in the control and maintenance of the vaginal bacterial microflora. Rev. Infect. Dis. 12, 856-872. doi: 10.1093/clinids/12.5.856

Reid, G., Beuerman, D., Heinemann, C., and Bruce, A. W. (2001). Probiotic Lactobacillus dose required to restore and maintain a normal vaginal flora. FEMS Immunol. Med. Microbiol. 32, 37-41. doi: 10.1111/j.1574-695X.2001. tb00531.x

Reid, G., Younes, J. A., Van der Mei, H. C., Gloor, G. B., Knight, R., and Busscher, H. J. (2011). Microbiota restoration: natural and supplemented recovery of human microbial communities. Nat. Rev. Microbiol. 9, 27-38. doi: 10.1038/ nrmicro2473

Ronnqvist, P. D., Forsgren-Brusk, U. B., and Grahn-Hakansson, E. E. (2006) Lactobacilli in the female genital tract in relation to other genital microbes and vaginal pH. Acta Obstet. Gynecol. Scand. 85, 726-735. doi: 10.1080/ 00016340600578357

Russell, J. B., and Diez-Gonzalez, F. (1998). The effects of fermentation acids on bacterial growth. Adv. Microb. Physiol. 39, 205-234. doi: 10.1016/S00652911(08)60017-X

Saba, E., Grivel, J. C., Vanpouille, C., Brichacek, B., Fitzgerald, W., Margolis, L., et al. (2010). HIV-1 sexual transmission: early events of HIV-1 infection of human cervico-vaginal tissue in an optimized ex vivo model. Mucosal Immunol. 3, 280-290. doi: 10.1038/mi.2010.2

Sewankambo, N., Gray, R. H., Wawer, M. J., Paxton, L., McNaim, D., WabwireMangen, F., et al. (1997). HIV-1 infection associated with abnormal vaginal flora 
morphology and bacterial vaginosis. Lancet 350, 546-550. doi: 10.1016/S01406736(97)01063-5

Sha, B. E., Zariffard, M. R., Wang, Q. J., Chen, H. Y., Bremer, J., Cohen, M. H., et al. (2005). Female genital-tract HIV load correlates inversely with Lactobacillus species but positively with bacterial vaginosis and Mycoplasma hominis. J. Infect. Dis. 191, 25-32. doi: 10.1086/426394

Siroli, L., Patrignani, F., Serrazanetti, D. I., Parolin, C., Nahui Palomino, R. A., Vitali, B., et al. (2017). Determination of antibacterial and technological properties of vaginal lactobacilli for their potential application in dairy products. Front. Microbiol. 8:166. doi: 10.3389/fmicb.2017. 00166

Spear, G. T., Sikaroodi, M., Zariffard, M. R., Landay, A. L., French, A. L., and Gillevet, P. M. (2008). Comparison of the diversity of the vaginal microbiota in $\mathrm{HIV}$-infected and HIV-uninfected women with or without bacterial vaginosis. J. Infect. Dis. 198, 1131-1140. doi: 10.1086/591942

Srinivasan, S., and Fredricks, D. N. (2008). The human vaginal bacterial biota and bacterial vaginosis. Interdiscip. Perspect. Infect. Dis. 2008:750479. doi: 10.1155/ 2008/750479

Taha, T. E., Hoover, D. R., Dallabetta, G. A., Kumwenda, N. I., Mtimavalye, L. A., Yang, L. P., et al. (1998). Bacterial vaginosis and disturbances of vaginal flora: association with increased acquisition of HIV. AIDS 12, 1699-1706. doi: 10.1097/00002030-199813000-00019

Tang, H. M., Ou, W. B., and Zhou, H. M. (2003). Effects of lactic acid and $\mathrm{NaCl}$ on creatine kinase from rabbit muscle. Biochem. Cell Biol. 81, 1-7. doi: 10.1139/ o02-168
Tevi-Benissan, C., Belec, L., Levy, M., Schneider-Fauveau, V., Si Mohamed, A., Hallouin, M. C., et al. (1997). In vivo semen-associated $\mathrm{pH}$ neutralization of cervicovaginal secretions. Clin. Diagn. Lab. Immunol. 4, 367-374.

Vanpouille, C., Arakelyan, A., and Margolis, L. (2012). Microbicides: still a long road to success. Trends Microbiol. 20, 369-375. doi: 10.1016/j.tim.2012.05.005

Vanpouille, C., Biancotto, A., Lisco, A., and Brichacek, B. (2007). Interactions between human immunodeficiency virus type 1 and vaccinia virus in human lymphoid tissue ex vivo. J. Virol. 81, 12458-12464. doi: 10.1128/JVI.00326-07

Wiesenfeld, H. C., Hillier, S. L., Krohn, M. A., Landers, D. V., and Sweet, R. L. (2003). Bacterial vaginosis is a strong predictor of Neisseria gonorrhoeae and Chlamydia trachomatis infection. Clin. Infect. Dis. 36, 663-668. doi: 10.1086/ 367658

Conflict of Interest Statement: The authors declare that the research was conducted in the absence of any commercial or financial relationships that could be construed as a potential conflict of interest.

Copyright (C) 2017 Nahui Palomino, Zicari, Vanpouille, Vitali and Margolis. This is an open-access article distributed under the terms of the Creative Commons Attribution License (CC BY). The use, distribution or reproduction in other forums is permitted, provided the original author(s) or licensor are credited and that the original publication in this journal is cited, in accordance with accepted academic practice. No use, distribution or reproduction is permitted which does not comply with these terms. 